\title{
MEMÓRIAS MIDIATIZADAS: A NOÇÃO DE CIÊNCIA CONSTRUÍDA PELOS INDIVÍDUOS A PARTIR DO CONSUMO MIDIÁTICO
}

\author{
MEDIATED MEMORIES: THE NOTION OF SCIENCE BUILT BY \\ INDIVIDUALS FROM MEDIA CONSUMPTION \\ MEMORIAS MEDIATIZADAS: LA NOCIÓN DE CIENCIA CONSTRUIDA POR
LOS INDIVIDUOS A PARTIR DEL CONSUMO DE LOS MÉDIOS
}

Kênia Beatriz Ferreira Maia

UFRN

keniamaia@yahoo.com

Emily Gonzaga de Araújo

UFRN

gonzaga_araujo@yahoo.com.br

\section{Resumo}

Este artigo tem como objeto o fenômeno sociocultural da midiatização (Fausto Neto, 2008; Sodré, 2002), visualizado a partir da recepção, no qual é destacado o processo de consumo simbólico com o conteúdo midiático (García Canclini, 1999) e seu entrelaçamento com elementos extra-midiáticos, recuperados segundo as mediações de Martín-Barbero (2006). Para tanto, realizamos entrevistas com dez pessoas em uma fábrica relacionada à Informática e instalada na região metropolitana de Natal (Rio Grande do Norte). A intenção foi, por meio de suas narrativas (os discursos de memória), perceber as dinâmicas do consumo midiático no recorte escolhido, o tema ciência. No trabalho de campo, usamos a técnica das entrevistas em profundidade, no qual a fala de nossos entrevistados constituiu nosso corpus.

Palavras-chave: Recepção. Midiatização. Consumo midiático.

\begin{abstract}
This article is about the sociocultural phenomenon of mediatization (Fausto Neto, 2008; Sodré, 2002), taken from the angle of reception, in which we emphasize the process of symbolic consumption with media content (García Canclini, 1999) and its interweaving with extra-media elements, recaptured from the perspective of mediations by Martín-Barbero (2006). Thus, we conducted interviews with ten employees from a Computing-related industry, installed in the metropolitan region of Natal (state of Rio Grande do Norte). Our goal was, through their narratives (the discourses of memory), try to understand the dynamics of media consumption about the subject science. In field work, we used the technique of indepth interviews, so that the speech of our interviewers was our corpus.
\end{abstract}

Keywords: Reception. Mediatization. Media Consumption. 


\section{Resumen}

Este artículo habla sobre el fenómeno sociocultural de la mediatización (Fausto Neto, 2008; Sodré, 2002), que se ve desde la recepción, donde se destaca el proceso de consumo simbólico con contenido multimedia (García Canclini, 1999) y su entramado de significados con los elementos extra de los medios, de acuerdo con la perspectiva de las mediaciones de Martín-Barbero (2006). Así, llevamos a cabo entrevistas con diez personas, empleados de una industria relacionada a Informática y instalada en la región metropolitana de Natal (Rio Grande do Norte). La intención era, a través de sus relatos (discursos de la memoria), entender la dinámica del consumo de los medios en la área seleccionada, el tema ciencia. Durante el trabajo de campo, se utilizó la técnica de entrevistas en profundidad, donde el discurso de los entrevistados constituyeron nuestro corpus.

Palabras clave: Recepción. Mediatización. Consumo de los medios.

O conhecimento acumulado na pesquisa em comunicação nos evidencia que a presença da mídia alterou sobremaneira nossa forma de viver, nossa experiência, tanto enquanto indivíduos como em termos de coletividade. Indagar o que os meios fazem conosco - e o que nós fazemos com eles - é uma provocação que não é de hoje nos estudos da mídia e que se mantém em aberto, revelando a complexidade que a questão comporta, bem como a dinamicidade que os processos da comunicação assumem no contexto da cultura contemporânea.

Quem deseja vislumbrar os traços da resposta a essa questão é instigado a descer mais profundamente nas camadas que permeiam nossa relação com a mídia. Este foi o intento quando nos propusemos a fazer uma incursão tomando como objeto um fenômeno' ${ }^{1}$ a midiatização, (Fausto Neto, 2008; Sodré,2002)

Já não é mais novidade falar que vivemos em uma sociedade "midiatizada", isto é, na qual a presença das mídias no cotidiano do indivíduo é intensificada, de modo que os meios e as dimensões imbricadas neles passam a ser elementos integrantes do processo de estruturação da sociedade e da elaboração da realidade (noção do real). O fluxo da informação e o processo de produção e apropriação de sentidos são reconfigurados no curso deste fenômeno, desdobrando-se em diversas práticas sociais, evidenciadas de maneira tão clara em nosso tempo pelas novas sociabilidades.

\footnotetext{
1 "MEMÓRIAS MIDIATIZADAS: percepções sobre ciências reconfiguradas a partir do consumo midiático", Dissertação de Mestrado (2011). Autor (orientador da dissertação) e Co-autor .
} 
Fausto Neto (2008, p. 2) afirma que a midiatização “(...) resulta da evolução de processos midiáticos que se instauram nas sociedades industriais". Esses processos dizem respeito à convergência de fatores sócio-tecnológicos, principalmente nas últimas três décadas, os quais produziram profundas e complexas alterações na nossa constituição societária. O autor fala da disseminação de protocolos técnicos em toda extensão da organização social e da intensificação da transformação de tecnologias em meios de produção, circulação e recepção de discursos. Para ele, o que precisamente distingue esta sociedade midiatizada de sua precedente é o protagonismo dos meios nos modos de estruturação e funcionamento das dinâmicas sociais.

Já não se trata mais de reconhecer a centralidade dos meios na tarefa de organização de processos interacionais entre os campos sociais, mas de constatar que a constituição e o funcionamento da sociedade - de suas práticas, lógicas e esquemas de codificação - estão atravessados e permeados por pressupostos e lógicas do que se denominaria a "cultura da mídia". Sua existência não se constitui fenômeno auxiliar, na medida em que as práticas sociais, os processos interacionais e a própria organização social, se fazem tomando como referência o modo de existência desta cultura, suas lógicas e suas operações (FAUSTO NETO, 2008, p. 4).

Sodré (2002), por sua vez, compreende a midiatização em termos de uma "qualificação virtualizante" da vida. Observando a passagem do que denomina "mídia tradicional ou linear" para as teletecnologias e/ou comunicação em rede, verifica a mudança de paradigma de uma comunicação centralizada, vertical e unidirecional para um universo de novas possibilidades no bojo da hipermídia, a exemplo da interatividade e multimidialismo. Possibilidades essas que, para o autor, se realizam e se evidenciam em uma tendência à virtualização.

Tudo isto, associado a um tipo de poder designável como 'ciberocracia', confirma a hipótese, já não tão nova, de que a sociedade contemporânea (dita "pós-industrial") rege-se pela midiatização, quer dizer, pela tendência à virtualização ou telerrealização das relações humanas, presente na articulação do múltiplo funcionamento institucional e de determinadas pautas individuais de conduta com as tecnologias da comunicação. A estas se deve a multiplicação das tecnointerações setoriais (SODRÉ, 2002, p. 21).

Dessa forma, Sodré (2002,p. 25-26) menciona a existência de um "quarto bios". Recuperando aqui as ideias aristotélicas em relação às dimensões da existência, a quarta - e hodierna - ambiência seria precisamente a midiática, companheira da vida contemplativa (bios theoretikos), política (bios politikos) e do prazer (bios apolaustikos). Em outras 
palavras, este autor expressa a "afetação das formas de vida tradicionais por uma qualificação de natureza informacional”.

Estamos tomando aqui, quanto à midiatização, o pensamento de autores que nos levam a perceber a "onipresença da realidade midiática" (SANTAELLA, 2002) em nosso contexto. Isso significa, em outras palavras, a intensificação da cultura midiática em termos de vida em sociedade e, mais precisamente nos últimos trinta anos, de uma cultura midiática alinhada ao virtual, às tecnologias advindas das telecomunicações.

Assim, nos parece cabível falar em processos complexos de negociação, assinalados por continuidades e descontinuidades. Em coexistência da cultura midiática com outras formas de cultura, fomentando um envoltório cultural heterogêneo, por assim dizer "híbrido" (GARCÍA CANCLINI, 2006). Tal postura apresenta-se, para nós, mais consoante com uma percepção adequada: nem desmerece ou desvaloriza a força simbólica do campo midiático e nem reduz a capacidade crítica e proativa dos sujeitos receptores.

Precisaremos examinar a mídia como um processo, como uma coisa em curso e uma coisa feita, e uma coisa em curso e feita em todos os níveis, onde quer que as pessoas se congreguem no espaço real ou virtual, onde se comunicam, onde procuram persuadir, informar, entreter, educar [...] Entender a mídia como um processo - e reconhecer que o processo é fundamental e eternamente social - é insistir na mídia como historicamente específica. [...] Entender a mídia como processo também implica um reconhecimento de que ele é fundamentalmente político ou talvez, mais estritamente, politicamente econômico (SILVERSTONE, 2005, p. 16-17).

No eco das considerações de Silverstone (2005), estamos concebendo mídia para além dos suportes técnicos, isto é, dos meios propriamente ditos. Ela é um ente social que diz respeito às construções de significados, valores e práticas (WOLF, 2005), e por isso mesmo está relacionada à experiência do indivíduo, à tessitura dos modos de vida em sociedade, nas suas diversas esferas de socialização. Conforme aponta Sodré (2002), ela é ambiência; é mediação (MARTÍN-BARBERO, 2006); é fenômeno sociocultural em contínuo, o qual se articula e dialoga com outras dimensões (política, econômica, histórico-conjuntural, etc.) e não existe apartada delas.

Não obstante, o entendimento que temos de nossa relação com os meios e sua cultura pode ser compreendida pelo viés do consumo.

Consumimos a mídia. Consumimos pela mídia. Aprendemos como e o que consumir pela mídia. Somos persuadidos a consumir pela mídia. [...] Consumimos objetos. Consumimos bens. Consumimos informação. Mas, 
nesse consumo, em sua trivialidade cotidiana, construímos nossos próprios significados, negociamos nossos valores e, ao fazê-lo, tornamos nosso mundo significativo (SILVERSTONE, 2005, p. 150).

Consumo este onde os elementos midiáticos dos quais o indivíduo se apropria entrelaçam-se com outros de sua experiência. Sobre estes outros, evocamos atores de natureza não-midiática, provenientes do contexto (relações sociais diretas e indiretas; grupo ou setor sócio-econômico, dentre outros) e da subjetividade (aqui, nos será válido pôr em relevo mais adiante a dimensão da memória).

Para esclarecer do que estamos falando exatamente quando situamos estes "outros", é pertinente pontuar sobre a perspectiva das mediações, de Martín-Barbero. Elas são elementos constituintes de nossa experiência; são dimensões intrínsecas ao viver em sociedade, as quais possuem um efeito engendrador de nossa forma de vida. Para Martino (2009, p. 179), mediações são “(...) as estruturas de construção de sentido às quais o receptor está vinculado" e abarcam aspectos como história pessoal, cultural de grupo, relações sociais imediatas e capacidade cognitiva, para dar exemplos. A mídia, por sua vez, também é uma mediação². Dessa maneira, as mediações também nos valem como uma espécie de "pano de fundo" sobre o qual as apropriações do conteúdo midiático se debruçam; aí, também se articulam. Estes mecanismos estão diretamente relacionados com a construção de nossas visões de mundo.

A perspectiva das mediações mantém íntima relação com a teoria sociocultural do consumo, principalmente em García Canclini (1999). Além de alinhar consumo à recepção, ele mostra como as práticas de consumo são, na verdade, práticas sociais. O consumo é visto como vetor de produção de sentido e ressignificação à medida que é mediação nas trocas objetivas e simbólicas entre os indivíduos.

O consumo é o conjunto de processos socioculturais em que se realizam a apropriação e os usos dos produtos. Esta caracterização ajuda a enxergar os atos pelos quais consumimos como algo mais do que simples exercícios de gostos, caprichos e compras irrefletidas, segundo os julgamentos moralistas, ou atitudes individuais (GARCÍA CANCLINI, 1999, p. 77).

\footnotetext{
${ }^{2}$ Daí surge um trocadilho: a mediação da mídia seria uma "midiação" (POLITSCHUK; TRINTA, 2003).
} 
Para completar nosso horizonte conceitual, agregamos a dimensão da memória. Recuperada sob a ótica da história de vida, ela diz respeito ao acervo pessoal de registros de nossa experiência como um todo, ainda que essa se desdobre em múltiplos episódios, tais como as faces de um diamante que é perpassado por um feixe de luz. Dito de outra forma, trata-se de uma "instância reconstituidora do passado" que habita dentro de nós (SARLO, 2007, p. 28).

Segundo Maurice Halbwachs (2004), a experiência da memória não é estritamente individual, pessoal. Nossas impressões podem se apoiar não somente sobre nossa lembrança, mas também sobre as dos outros. Teríamos então, na evocação do lembrar, uma experiência partilhada. Nossas lembranças permanecem coletivas mesmo que tratemos de momentos onde somente nós estivemos presentes, por que "nunca estamos sós": levamos os outros dentro de nós (HALBWACHS, 2004, p. 30). Logo, o ato de lembrar é coletivo e pessoal ao mesmo tempo, onde o indivíduo entra e sai de grupos sociais.

No âmbito desses grupos pelos quais passeamos socioculturalmente, expomos nossas percepções, nossas visões de mundo, e também internalizamos algo da percepção coletiva com a qual tivemos contato. Fazemos trocas simbólicas. Em nós, estão verdadeiros "palimpsestos", isto é, tramas de textos entrecruzados cuja procedência mescla fontes midiáticas e não-midiáticas, as quais se inscrevem na memória dos sujeitos (BONIN, 2006, p. 134).

A memória nos serviu como operador teórico para uma finalidade específica: por meio de discursos produzidos em seu âmbito, alcançarmos empiricamente a midiatização e o consumo midiático.

\section{Empiria}

Utilizando da técnica das entrevistas em profundidade, objetivamos visualizar nas narrativas dos entrevistados - isto é, por meio dos seus discursos de memória e, ao mesmo tempo, de consumo simbólico sobre o recorte temático definido - como essas pessoas reproduzem suas percepções reconfiguradas a partir da midiatização, deixando entrever as reverberações entre aquilo que se apropriaram na mídia com informações provenientes de 
outras esferas de socialização (âmbito familiar, escolar, de trabalho, etc). Essa reconfiguração é como que a "partícula visível" da midiatização enquanto fenômeno sociocultural que captamos. Junto a ela - e, possivelmente, tão imbricadas a ponto de não conseguirmos dissociá-las - estão as práticas sociais, as quais constituíram-se como fio condutor de todo raciocínio teórico-metodológico do trabalho.

Nosso eixo temático foi "ciência". Poderíamos ter escolhido outro assunto para nortear nossa conversa com os entrevistados, contudo, selecionar a ciência - ainda que não seja aquela em seu estado mais original, uma vez que está no âmbito do discurso midiático e é modificada por ele - nos permite perceber, por conseguinte, do ponto de vista do receptor, como as mídias estão contribuindo com seu papel de difusão de conhecimento, de colaboradoras na formação intelectual/cultural do indivíduo em tempos de aprendizado multi-tarefa, isto é, um no qual a aquisição de saberes não se dá apenas nos domínios escolares, nos territórios tradicionais da educação formal ${ }^{3}$, mas se amplia para vias alternativas.

A etapa empírica propriamente dita foi realizada nas dependências de um ambiente industrial, em uma fábrica relacionada à Informática e instalada na região metropolitana de Natal (Rio Grande do Norte) na primeira semana do mês de agosto de 2010. Realizamos entrevistas em profundidade na modalidade semi-aberta (o entrevistador tem um roteiro de perguntas). A fala de nossos entrevistados (total de dez) constituiu nosso corpus, de modo que, por meio de suas narrativas (os discursos de memória), percebemos as dinâmicas do consumo midiático no recorte escolhido.

Definiu-se um perfil: pessoas de ambos os sexos, cujas idades estivessem entre 18 e 35 anos, entendendo que nesta faixa etária conseguiríamos alcançar um público jovem, em princípio mais familiarizado com os segmentos de mídia disponíveis no contexto sociocultural nacional e local (veículos impressos, rádio, televisão e Internet), isto é, seriam usuários mais prováveis destas mídias. Além disso, estariam situados em um estágio de vida no qual boa parte da educação formal (nível médio completo ou incompleto; nível superior em andamento ou concluído) já teria sido cumprida, em tese; isso nos sinalizava que os entrevistados já seriam iniciados no tema ("ciência"). Por fim, preferimos optar por indivíduos legalmente responsáveis, isto é, maiores de dezoito anos, para eliminar a questão da autorização de pais ou tutores.

\footnotetext{
${ }^{3} \mathrm{O}$ livro, o professor e o ambiente de ensino, por exemplo.
} 
No tocante ao tempo, definimos que o máximo de duração das entrevistas seria de 60' (sessenta minutos). No entanto, durante a realização das mesmas, percebeu-se que a conversa com as fontes, na maioria das vezes, não extrapolava os trinta minutos. $\mathrm{O}$ instrumento de coleta utilizado foi a gravação de áudio.

Nossos entrevistados ficaram, então, assim relacionados (indicados por pseudônimos, a fím de respeitar o sigilo de suas identidades ${ }^{4}$, porém mantendo a identificação de gênero):

1. João (nível superior incompleto; 31 anos; setor administrativo);

2. Antônio (nível superior como tecnólogo; 26 anos; setor de criação);

3. Isabel (nível médio; 22 anos; setor administrativo);

4. Charles (nível superior incompleto; 23 anos; setor técnico);

5. Gastão (nível superior em curso; 24 anos; setor de produção);

6. Bertoldo (nível superior incompleto; 34 anos; setor técnico);

7. Lavínia (nível médio; 22 anos; setor administrativo);

8. Francisco (nível superior em curso; 31 anos; setor técnico);

9. Inácio (nível superior em curso; 34 anos; setor de criação);

10. Cíntia (nível superior como tecnóloga; 30 anos; setor de controle);

As perguntas cujas respostas foram mais significativas para nossas análises constituíram-se em três: na primeira, se o entrevistado(a) tinha ou não interesse sobre ciência. Quando a resposta era positiva, lhe pedíamos que mencionasse alguma lembrança sobre o assunto que estivesse situada no contexto da mídia. Já na segunda pergunta, tratávamos de saber o quê é ciência para ele(a) e, por fim, se este identificava diferenças entre o conhecimento científico e outros tipos de conhecimento (senso comum, sabedoria popular, etc.). Desse modo, no primeiro questionamento, procuramos captar por meio do "fazer memória" de nossos respondentes a midiatização enquanto fenômeno (leia-se aqui as narrativas proferidas pelos sujeitos).

$\mathrm{Na}$ segunda e na terceira pergunta, objetivamos visualizar a matriz de pensamento dos nossos entrevistados sobre o nosso recorte. Aqui, percebemos repertório cultural; níveis de iniciação no campo científico e, sobretudo, visão acerca de ciência; não obstante, percebemos como as apropriações midiáticas vão agregando elementos para este repertório, fornecendo assim referências para construção desta visão que o indivíduo tem/faz de ciência. Apareceram de maneira mais evidente os palimpsestos dos quais falamos anteriormente.

\footnotetext{
${ }^{4}$ Um dos requisitos enfatizados no termo de consentimento para participação na pesquisa.
} 
O bloco analítico do trabalho foi dividido em duas partes maiores, as quais funcionaram também como categorias analíticas: a primeira, intitulada Discursos de memória midiatizada, foca-se na midiatização e no consumo. A última parte, Percepções de ciência, centralizou-se nas matrizes de pensamento sobre o tema.

Para ambas as partes, foram utilizados operadores analíticos, definidos segundo premissas advindas da perspectiva das mediações. Constaram de três variáveis, as quais constituíram-se como mediações: família e cotidiano, repertório cultural e formação continuada e crenças. Quanto à família e cotidiano, tratamos do ambiente familiar ${ }^{5}$ e/ou doméstico como um lugar primeiro de socialização, isto é, uma esfera fundamental na constituição da experiência do indivíduo. Nas palavras de Martín-Barbero (2006, p. 295), está aí a "situação primordial de reconhecimento", no qual a cotidianidade familiar é um "lugar social de uma interpelação fundamental para os setores populares". É também no âmbito familiar que transcorre o tempo da cotidianidade, “(...) um tempo repetitivo, que começa e acaba para recomeçar (...)” (MARTÍN-BARBERO, 2006, p. 297); este tempo comporta a recursividade das interações, das práticas e dos fluxos que dão sentido ao dia-a-dia dos sujeitos e são naturalizados no "comum", no ordinário da rotina diária.

Já em repertório cultural e formação continuada, fizemos referência ao acervo intelectual do indivíduo e as competências desenvolvidas a partir deste, considerando aqui matizes de conhecimento provenientes tanto da educação formal quanto de outras fontes, as quais constituem saberes de outras ordens (cunho artístico-cultural, cunho popular ou vinculado a alguma tradição específica, experiência de vida, etc.). Preferimos aliar a expressão formação continuada neste operador para enfatizar o caráter processual e contínuo na construção deste repertório.

Nas crenças, detivemo-nos no campo dos saberes dignos de credibilidade e adesão por parte do indivíduo, isto é, aqueles nos quais ele acredita e deposita confiança em graus diversos. Entram neste hall as crenças de cunho religioso, científico e popular (vinculadas ao senso comum), dentre outras. Muito embora esta nomenclatura não seja usada por MartínBarbero (2006) como uma mediação específica a rigor, pensamos que não fugimos da ideia deste autor quando desmembramos as crenças e as elevamos como parâmetro significativo o

\footnotetext{
${ }^{5}$ Família para além dos vínculos biológicos, abrangendo também a dimensão dos amigos e demais pessoas de convívio mais próximo.
} 
suficiente para constituir uma mediação particular. $O$ universo das crenças também está inserido na cotidianidade como um filtro mediador do mundo à nossa volta; elas dizem respeito a um campo de representações bastante considerado pelos sujeitos, conforme percebemos na fala de nossos entrevistados.

As tabelas abaixo expressam os hábitos de consumo midiático dos nossos entrevistados, conforme seu acesso e uso dos meios. Foram elaboradas com base nas suas respostas de modo geral (na conversa inteira, e não somente em uma resposta específica). Muito embora este dado - eminentemente quantitativo - não diga tudo que traduz as práticas relativas ao consumo midiático destes indivíduos, ela aponta elementos significativos nessa direção. Também nos sinaliza midiatização que pode se realizar como uma tendência à virtualização, a um multimidialismo centrado nas hipermídias, na cibercultura ${ }^{6}$. Note-se que, à exceção de Lavínia, todos os demais situaram a Internet em primeiro lugar, citando os demais meios que utilizam em segundo e/ou terceiro plano.

\begin{tabular}{|c|c|c|c|c|c|}
\hline & $\begin{array}{c}\text { Jornal } \\
\text { impresso }\end{array}$ & Revistas & Rádio & Televisão & Internet \\
\hline Antônio & & & & $x$ & $x$ \\
\hline Bertoldo & & $x$ & & $x$ & $x$ \\
\hline Cíntia & & & $x$ & & $x$ \\
\hline Charles & & $x$ & & $x$ & $x$ \\
\hline Francisco & $x$ & $x$ & & & $x$ \\
\hline Inácio & & & & $x$ & $x$ \\
\hline Lavínia & & $x$ & $x$ & $x$ & $x$ \\
\hline Isabel & & & & & $x$ \\
\hline João & & & & & $x$ \\
\hline Gastão & & & & $x$ & $x$ \\
\hline
\end{tabular}

Tabela 01 - Qual o meio de comunicação que mais usa para se informar?

\footnotetext{
${ }^{6}$ Uma observação que se restringe aos nossos entrevistados, sem caráter generalizante.
} 


\begin{tabular}{|c|c|}
\hline De 06 a 08 horas/diárias & $\begin{array}{c}\text { 10 horas, em média } \\
\text { (consumo que se dá em horário de trabalho; } \\
\text { motivações relativas a este fim) }\end{array}$ \\
$\begin{array}{c}\text { (consumo que se dá para além do horário de } \\
\text { trabalho; há interesse do indivíduo em realizá-lo } \\
\text { durante seu tempo livre, geralmente antes do } \\
\text { expediente ou após seu retorno ao ambiente } \\
\text { doméstico) }\end{array}$ \\
\hline João, Isabel e Gastão & $\begin{array}{c}\text { Antônio, Charles, Bertoldo, Lavínia, Francisco, } \\
\text { Inácio e Cíntia }\end{array}$ \\
\hline
\end{tabular}

Tabela 02- Tempo despendido no consumo midiático

Vale ressaltar que, nas tabelas acima, a mensuração deue em termos de rotina de nossos entrevistados durante os dias úteis da semana (de segunda à sexta-feira), não abrangendo seus hábitos em dias de sábado e domingo, quando não ocorre o regime de trabalho formal. Nos fins de semana, o consumo midiático deles assume outros ordenamentos (quantidade de horas, preferência por determinados meios em relação a outros) por motivações diversas (lazer pessoal ou familiar, descanso, dentre outros), os quais não aprofundamos ${ }^{7}$.

\section{Discursos de memória midiatizada}

Neste bloco, percebemos que a formação intelectual exerce forte influência mediadora enquanto delimitador de conteúdo no consumo midiático. Compreendendo que a formação intelectual e o repertório acumulado (em termos de saberes relacionados à educação formal) mantêm íntima relação com a área de atuação profissional, verificamos que o consumo de mídia está, não raro, em um primeiro momento, vinculado à demanda de qualificação para o mercado de trabalho. O estar informado quanto a motivações de ordem pessoal aparece depois.

\footnotetext{
${ }^{7} \mathrm{O}$ cálculo dos valores mencionados é simples: o expediente diário semanal corresponde de seis a oito horas, de modo que um consumo mais restrito ao ambiente de trabalho seja mais ou menos equivalente a isso; no caso daqueles que citaram um consumo para além desse período, convencionamos quantificar esse excedente em duas horas além do relacionado ao expediente, incluindo neste índice os telejornais (alguns os assistem antes de sair para trabalhar, pela manhã, enquanto outros o fazem ao retornar para casa, à noite, ou no fim de noite/madrugada, após retornar da faculdade), os filmes (preferencialmente à noite), a leitura de revistas e/ou jornais e os programas de rádio (situação semelhante a do consumo de telejornais).
} 
Esse traço se sobressaiu fortemente na conversa com Bertoldo e Charles; eles falaram demoradamente sobre o consumo de informação na mídia relacionado às suas áreas de interesse antes que pudéssemos adentrar no assunto central da entrevista. O primeiro, por exemplo, mencionou a nanotecnologia, citando uma matéria que viu no site Convergência digital, hospedado pelo portal Uol, que falava de tendências para "nanotecnologizar" baterias e demais aparelhos. Ele próprio explicou do que se tratava o termo antes mesmo que isso lhe fosse pedido: “(...) fazer uma coisa que ocupava um espaço maior, fazer a mesma coisa em um espaço menor e acrescentar mais recursos".

Bertoldo encarna o perfil do "workaholic", isto é, das pessoas que respiram sua realidade profissional mesmo fora do ambiente corporativo. Atuando em Tecnologia da Informação, o uso que faz dos meios é intimamente vinculado a isso. O meio que mais utiliza para se informar é a Internet, dedicando a maior parte de sua navegação virtual a conteúdo relacionado com sua área (sites de fabricantes, blogs, fóruns de discussão sobre tópicos do mundo da informática). Mesmo quando acessa portais, escolhe o que vai ler muito motivado pela vinculação da matéria com o campo da tecnologia. Em sua fala, comenta ainda que se interessa pelas notícias de economia, por exemplo, quando vê se tratar de algo relacionado ao Programa de Aceleração do Crescimento (PAC), pois sabe que a Tecnologia da Informação é contemplada pelo governo neste pacote (Internet para todos). Lê revistas com frequência, sendo estas focadas em programação, redes e banco de dados. Em televisão, assiste preferencialmente noticiários (Jornal Nacional, Jornal da Band, Jornal da Record, Jornal da Globo) e, às vezes, filmes. Em princípio, temos a nítida impressão de que seu interesse em ciência percorre apenas as vias por onde esta se aproxima da tecnologia. No entanto, quando o questionamos sobre sua lembrança de alguma coisa sobre ciência vista na mídia, sua primeira menção é sobre o antigo embate entre as visões científica e religiosa acerca de certos fenômenos.

Ele cita a noticia que leu em uma revista semanal, de atualidades, possivelmente Veja ou Época, sobre a simulação do Big-Bang feita na Suíça, onde cientistas tentavam reproduzir a origem do universo, e afirma sua opinião diante da polêmica: "(...) Eu vejo que muitas pessoas utilizam a religião como... conformismo; sem pensar se isso é real ou não. Eu acho que tem aí um dado muito importante, que é a fé; seja na religião ou não, a fé, eu acho que... Movimenta montanhas. (...) Foi comprovado cientificamente que a pessoa que te fé...A possibilidade de se curar de doenças é superior a de uma pessoa que já se entregou". 
Charles, por sua vez, lembrou primeiramente da entrevista de Steve Ballmer, diretor da Microsoft, falando sobre as ferramentas de comunicação instantânea via Internet. O entrevistado citou uma declaração de Ballmer na qual o Brasil seria o país com o mais alto número de usuários de MSN no mundo até 2012 ou 2014 (o entrevistado não sabia precisar a data). A visita se deu pelo lançamento de uma versão nova deste software, e, segundo reportou Charles, a escolha do Brasil se deu pelos altos índices dos brasileiros em relação à quantidade de horas na Internet.

Charles entende que atualizar-se faz parte de seu trabalho, principalmente dentro da área em que atua (Informática). "Informação é poder", afirma, e por isso mesmo a pesquisa faz parte de seu hábito profissional. Internet e revistas são os meios que mais utiliza, de maneira que assiste televisão geralmente ao fim do dia, quando retorna do trabalho ou da faculdade que faz à noite, em um quantitativo de tempo bastante reduzido em relação aos primeiros citados. Quando tem tempo, assiste o Jornal da Globo (último noticiário da emissora, exibido após as 23h).

Quando acessa a Internet, logo pela manhã, ele tem uma rotina em termos de navegação virtual: as primeiras páginas que acessa são as páginas do Globo.com e do jornal local Tribuna do Norte, a fim de atualizar-se tanto em relação às novas tecnologias quanto para "ter uma visão global do que está acontecendo no mundo". Depois, vai para as páginas de Informática (sites, blogs), direcionado para buscar conteúdo que lhe sirva em termos profissionais. No campo das revistas, Charles lê as específicas de sua área (RN Informática) e tem acesso a elas na empresa. Outras do tipo informativas, como Veja e Época, não as costuma ler. Quando questionado sobre seu interesse em ciência, Charles admite que o tema lhe passa despercebido; que não faz parte de seu foco, não lhe desperta muito interesse.

Diante dessa resposta, foi colocada para Charles (pelo entrevistador) a relação entre tecnologia e ciência, de modo a evidenciar que a área de atuação dele não está muito distante do campo científico. Posta a provocação e refeito o questionamento sobre a lembrança de alguma coisa vista na mídia sobre o tema, Charles fala de "computação nas nuvens", que se trata da possibilidade de armazenar informações não mais no HD do computador em que se opera ou em outras unidades materiais, mas no próprio servidor (na rede, daí a conotação de “nuvens"), disponível ao acesso em qualquer lugar onde haja conexão. "É a portabilidade dos arquivos", conforme sintetiza Charles, que viu o assunto em uma matéria publicada no site Globo.com, na seção sobre Tecnologia. Posteriormente, fez um curso voltado para assunto, de 
caráter presencial, e o fez porque percebeu naquele assunto específico a necessidade de qualificar-se para manter-se em dia com a demanda de seu mercado de trabalho.

Agora sim, "computação nas nuvens" e "ciência" têm tudo a ver segundo este entrevistado: “(...) Toda a parte de Informática está envolvida com ciência”, afirma. "Pesquisa", "inovação" e "atualização" lhes são palavras-chave tanto para o campo da tecnologia quanto para a ciência, e por isso acredita que "Ciência... Envolve planejamento, envolve pesquisa, envolve ação, execução... E tudo isso para se chegar a um resultado, a alguma coisa. (...) A palavra que vem em mim é a palavra ciência; é uma palavra de pesquisa, de apresentação (...) é você pesquisar uma nova tecnologia, um novo medicamento, uma nova espécie de animal; pesquisar aquele novo ser, ver as características dele (...) pegar essas informações, organizar e apresentar para o... O mundo”.

Em ambos os casos, a título de repertório cultural e formação continuada, percebemos que o viés midiático apareceu como agregador a uma formação inicial, esta construída em termos de escola e ensino superior. O componente midiático é apropriado com mais ênfase em termos de formação subsequente. Aqui, talvez não estejamos afirmando nada de novo; o dado relevante, contudo, nos pareceu ser a visualização dos fluxos de consumo simbólico, em seus ordenamentos; a dinâmica da interação, nas aproximações iniciais entre indivíduo e fenômeno. Não obstante, visualizar também as contradições entre o os interesses assumidos (ditos, colocados em nível de consciência professada, dita durante as conversas) e os mecanismos de funcionamento da memória midiatizada: Bertoldo afirma claramente seu interesse pela "fatia" da ciência que se relaciona com sua área profissional, mas seu primeiro registro (lembrança) narrado não se coaduna tanto com essa preferência manifestada.

Quanto à cotidianidade familiar, verificamos como esta mediação é um articulador subsequente (ou seja, em um contexto mais alinhado ao processo de ressignificação e posterior produção de sentido, este agora reconfigurado) em termos de consumo midiático: se traduz no comentário, na conversa informal de algum tema apropriado a partir da mídia com outros sujeitos integrantes ou pertinentes a essa dimensão. Isabel, durante o período que tinha assinatura semanal de uma revista especializada em ciência (um ano), fazia a troca da mesma com o primo que assinava uma publicação semelhante para, posteriormente, comentar com ele a respeito do que tinha considerado mais interessante. A essa altura, ela já havia concluído o ensino médio e estudava para o vestibular. Quando perguntada se buscou a assinatura também pela preparação para aquelas provas, consentiu que este também tinha sido um fator, 
mas a curiosidade foi de fato preponderante. Isabel assume seu gosto pela temática, mas pondera quando diz que nem tudo relacionado lhe causa interesse: "depende muito do assunto", afirma.

Para Isabel, ciência é algo "extraordinário", pois "sempre descobre algo novo". "Descoberta", "coisas inusitadas como o porco que brilha", "saúde", "cura de doenças": essas foram as noções que lhe vieram à mente sobre o que é ciência, bem como "cura de AIDS, cura de câncer”. Afirma: “(...) sempre penso em cura quando penso em ciência”. Ela citou ainda uma matéria que assistiu no noticiário de televisão sobre a possibilidade da cura para a AIDS em recém-nascidos como tendo sido algo que lhe marcoue chamou a atenção. Mais adiante, a entrevistada explicou que costumava ler muito sobre drogas, pois tinha amigos usuários dessas substâncias e entendia que sua atitude de buscar informação sobre o assunto lhe ajudaria a ter argumentos mais fortes para dialogar com eles no sentido de fazê-los desistir dessa prática: “(...) Você sabendo como a droga funciona, você pode querer usar ela para o mal ou para o bem. Tipo assim, tem gente que pode usar a informação para o bem ou para o mal. (...) Tipo, cocaína serve para tal coisa, então vou usar para dopar aquela menina e tal...”.

João, por sua vez, se lembrou de um debate com amigos, colegas da faculdade em que cursava na época, em torno do assunto "aquecimento global", o qual tinha visto na capa de uma revista, a qual não lembrava exatamente qual era, mas acreditava se tratar da revista Veja: “(...) Que era sobre a questão global (...) Uma questão que era levantada sobre se (...) a terra hoje consome mais do que o planeta pode oferecer; aliás, se os humanos hoje consomem mais do que a terra pode oferecer (...) A gente discutia bastante. Tem até um autor, que eu também não me lembro o nome, que um amigo me falou, que me recomendou a leitura, que ele defende a tese de que o ser humano é o câncer da terra; que a terra tem vida; é um ser que tem vida; claro, não pensa, mas como se fosse mais ou menos animado, aí eu achei bastante interessante mas não me aprofundei também não".

Mas a matéria da revista não foi a primeira lembrança citada por João. Este mesmo entrevistado tinha bem mais facilidade em situar registros relativos à ciêncianos filmes do cinema hollywoodiano ${ }^{8}$ do que em outras mídias. Ele expressou um imaginário de elementos pertinentes ao campo da ciência ancorados muito mais no patamar da ficção do que

\footnotetext{
8 "O dia em que a terra parou" (remake), “A Estrada" e "O livro de Eli”.
} 
propriamente em termos do "real", isto é, o que se espera dos meios de comunicação ditos "informativos", mais próximos da não-ficção.

Por isso mesmo, quão surpreendente nos foi perceber que, ainda no âmbito da midiatização, a ficção comunica mais ciência que os gêneros informativos. Não somente João, como outros entrevistados apresentaram mais referências de ciência relacionadas a formatos ficcionais (incluem-se aqui os documentários feitos para televisão com viés ficcional, como nos canais a cabo ou por assinatura). Foram feitas citações a filmes como "Armagedom", "O livro de Eli", "O dia em que a terra parou" e "A Estrada", além do documentário "A Terra sem ninguém", exibido pelo History Channel (versão do canal em português). Esse dado rompeu com nossas expectativas, pois esperávamos pela predominância de lembranças relacionadas a reportagens ou outros formatos eminentemente informativos e/ou opinativos, tanto em televisão como nos demais (Internet, revistas especializadas ou em jornal impresso). Admitíamos até uma possível menção a um artigo de algum cientista ou jornalista. Mas fomos oportunamente desconstruídos.

Voltando à fala de João, por exemplo, que estabelece comentários críticos sobre a questão do aquecimento global a partir das lembranças associadas a dois filmes, notamos a teia que o entrevistado vai compondo, conectando um assunto ao outro; a partir da reflexão feita por ele nos filmes (apropriação/reapropriação), ele migra para dimensões aparentemente não relacionadas:

(...) Por exemplo, aquele filme que foi um remake agora, com o Keanu Reeves, 'O dia em que a terra parou', porque que ele foi feito agora? (...) mas aquele filme já é de 58, nem lembro; poxa vida, o pessoal já tinha essa preocupação naquela época, alguma coisa deve estar acontecendo mesmo, embora muita gente comente que o aquecimento global é lorota, é coisa que foi inventado, mas acho que não; e aí você vai assistir outro; coincidentemente eu assisti dois filmes no final de semana que falavam já de um caos, não sei se você já assistiu 'A estrada' (...) Puxa vida, pouco tempo que eu assisti dois filmes com o mesmo tema e isso, assim, já tá ficando rotineiro, inclusive; se a gente for falar sobre aquecimento global (...). Se a gente realmente for conversar sobre aquecimento global, o cinema já é um braço, que se for pra alertar, se for realmente pra alertar ou só fazer filme mesmo, se for só para trabalhar em obras, literaturas que tão sendo faladas, mesmo que fictícias, chama a atenção de uma certa maneira. Eu estava até conversando um tempo desses sobre essas questões e (...) Não sei se os partidos políticos que têm essa bandeira de ambientais solicitam ou gritam por um espaço maior de uma maneira oportunista ou realmente de uma necessidade. Partido verde, por exemplo, não sei se... Não é uma coincidência, claro, que a nossa prefeita é do Partido Verde, mas ele vai ganhando um pouco mais força; não sei se é um oportunismo, não sei se é 
uma coisa à toa, não sei se isso vai ser uma ideologia mais para frente (...) (JOÃO, entrevistado).

Essa aproximação com a ciência, operada pela ficção, mantém relação importante com o campo da tecnologia:

\begin{abstract}
Assim, a ficção científica é uma narrativa resultante do processo da tecnociência e sua construção só foi possível porque seus autores procuraram explicitar as possibilidades ficcionais que a tecnologia de cada época, cada tempo, permitia. Acabaram por obter, assim, uma interseção entre narrativas, relatos e técnicas, ou seja, entre a arte e a ciência, cruzando as criações tecnológicas com os diálogos narrativos, ficcionais e literários. Como consequência direta, diminuíram as distâncias entre o universo científico, a linguagem da arte e a vida cotidiana (COUTINHO, 2008, p. 18).
\end{abstract}

No caso de nossos respondentes, as narrativas de ficção científica de fato estreitaram dois "mundos": o dos sujeitos e o da ciência, ainda que estas não tenham como objetivo primordial uma alfabetização científica a rigor. Sob um olhar mais criterioso, perceberemos que este tipo de ficção incorre, por vezes, em erros científicos (COUTINHO, 2008). Contudo, não há problema; este é o território da ficção, da literatura, da arte; a licença poética abre tal precedente.

Nesse sentido, é oportuna a noção de MEDEIROS (2011, p. 38), na qual “(...) a ficção científica não é sobre ciência, mas sobre a ideia que fazemos dela. Desse modo, torna-se possível dizer que o mais importante não é o futuro, mas como é projetado o futuro no presente". Estas proposições da autora nos servem para, aqui, estabelecer duas importantes conexões com os discursos de nossos entrevistados, mediante o nosso enfoque de pesquisa: o primeiro ponto é apreender que as narrativas de ficção científica apresentam, sobretudo, uma visão de ciência, uma percepção sobre o agir científico, seu método e suas implicações; o segundo é que, dado o caráter antecipatório característico à maioria dessas narrativas, elas propõem, além de uma visão específica de ciência, uma projeção sobre o futuro, de maneira tal que este futuro é fortemente perpassado pela ciência ${ }^{9}$, como que em boa medida alicerçado em referências científicas.

Gastão resumiu emblematicamente essa relação entre ciência e futuro a partir das narrativas de ficção científica. Para este entrevistado, a ciência não somente “(...) é o futuro”, mas um que é “(...) bem diferente do que é agora (...)”, intimamente associado à tecnologia

\footnotetext{
${ }^{9}$ Isso nos remete ao pensamento positivista de Auguste Comte: ciência/progresso/futuro. 
“(...) de ponta, senão não consegue bons resultados”. Esse caminho de mudanças rumo ao futuro comportaria, na visão do entrevistado, mudanças em regime gradativo, sem rupturas bruscas ou repentinas.

Ele se diz um homem atento quanto à sua necessidade de atualização. Utiliza mais a Internet como fonte de informação, de maneira que procura conteúdo tanto em termos profissionais, no que diz respeito a sua área, como também para inteirar-se dos acontecimentos (grandes portais, como Globo.com, Uol, Terra, e a página do jornal local Tribuna do Norte). Ele assiste pouco televisão devido ao tempo reduzido que dispõe para estar em casa, mas, quando pode, opta por noticiários, geralmente matutinos e às vezes os noturnos, dedicando mais atenção às notícias de economia e esporte. Além desses, vê programas de debate e/ou entrevista. Não costuma ouvir rádio e "nunca teve prazer" em ler jornal. Já em relação às revistas, lê as que são especializadas na sua área de atuação.

Em seu interesse sobre ciência, afirmou ter uma postura de quem procura saber um pouco de tudo, sem especializar-se em algum assunto à exceção do que diz respeito à sua área. Porém, gosta de ver coisas ligadas à ciência quando percebe se tratar de uma "descoberta", dependendo da ciência na qual esta esteja inserida. Ele explica que "alguma vez na vida aquilo vai servir para você, independente de você precisar agora ou daqui a um ano, a dois anos...Mas [é importante] você ter alguma informação daquilo”.

Para ele, “(...) todas as descobertas hoje, de alguma forma vai afetar na sua vida; na sua vida daqui a 5 anos, a 10 anos (...) na ciência, eu sempre acho que uma coisa puxa a outra, uma descoberta que puxa outra descoberta que puxa outra descoberta...Que de alguma forma, independente do lugar do mundo que seja, alguma coisa na sua vida pode lhe afetar", e é justamente por isso que, na visão de Gastão, a ciência aponta para o futuro.

\section{Considerações Finais}

A midiatização, enquanto fenômeno sobre o qual nos debruçamos, se verificou. Mas seus fluxos, seus ordenamentos não nos eram de todo previstos inicialmente. A partir da experiência de nossos respondentes, expressas em seus discursos, percebemos como ela se confirma, na prática, como uma tendência à virtualização; ao multimidialismo capitaneado pela hipermídia, pela cibercultura. Mas embora a preferência pelos meios se reconfigure, o 
uso de um e de outro se assemelha: a pauta de interesses dos entrevistados, quer seja na Internet, quer seja na televisão ou em mídias impressas, mostrou-se a mesma. Quem quer informação sobre ciência ou outro assunto (esporte, tecnologia, etc) vai buscá-la; o meio não inibe ou incita esse movimento em princípio; nesse sentido, a mediação da mídia (ou "midiação") não mudou muita coisa. Pelo menos não para os nossos entrevistados.

Por outro lado, onde a ficção aproximou mais os sujeitos do mundo da ciência, há um “agir" midiático que não pode ser desconsiderado. Ele não foge ao escopo da cultura do consumo pertinente ao contexto da sociedade midiatizada. Visões específicas da ciência são ensejadas, propostas. Consumidores apropriaram, ressignificaram e se tornaram produtores de sentido, manifestando suas percepções, evidenciando práticas sociais. A mídia encontrou eco nas representações manifestas pelos entrevistados.

No que tange às mediações e ao campo da memória, entendemos que esta associação se confirmou. A hipótese de Halbwachs (2004) de que a representatividade da lembrança está diretamente proporcional ao tempo de duração do grupo e à força do vínculo para seus integrantes obteve respaldo em nossa empiria. No partilhamento de vínculo, a mediação propiciou um grupo social, cujo desdobramento foi uma dimensão de memória coletiva a perpassar seus membros. Quando os vínculos eram efêmeros, a lembrança era mais fraca ou ausente do plano da consciência. O contrário também ocorreu: vínculos resistentes e/ou duradouros mantiveram a lembrança viva por mais tempo.

Além disso, visualizamos as mediações extra-midiáticas ora delimitando conteúdo $a$ priori, ora articulando conteúdo a posteriori. É claro que a mecânica real das mediações sempre analisada sob um ponto de vista interacional - é muito mais dinâmica, muito mais dialética; híbrida. Estamos bem lembrados de que o fenômeno que tomamos como objeto é fundamentalmente processual. Nossa captação dele pode ter sido apenas um frame. Nem por isso perde sua consistência, sua validade.

Não obstante, a tendência à concepção positivista da ciência ainda é presente no discurso midiático sobre ciência, conforme pudemos observar em nosso empírico ${ }^{10}$. É bom deixar claro que estamos falando de uma inclinação a uma determinada matriz de pensamento, sem absolutizá-la, deixando margens para abarcar outras noções na composição

\footnotetext{
${ }^{10}$ As análises específicas a estas conclusões estão presentes no segundo bloco analítico, Percepções de Ciência, as quais, por força de espaço, não recuperamos aqui.
} 
das visões acerca de ciência. Faz-se necessário adotar esta postura moderada porque foi isso que encontramos em nosso trabalho. Vale lembrar como, por vezes, percebíamos na fala da mesma pessoa pontos de aquiescência e de ruptura com o ideal científico calcado no positivismo.

Isso nos permitiu entrever tessituras híbridas nas visões de nossos entrevistados. Ao passo que encontramos indicadores pendentes para a concepção positivista (percepção da ciência como fonte de conhecimento superior em relação a outras formas; ciência e conhecimento proveniente das crenças religiosas como distintos e opostos, bem como a atribuição de confiabilidade à concepção científica baseada motivações da ordem da tangibilidade, concentração de referências que privilegiam certas áreas da ciência, principalmente as ciências exatas e naturais), também identificamos aqueles sugestivos a visões mais abrangentes (processo de construção do conhecimento na ciência segundo uma perspectiva não-linear; processo contínuo-inacabado; visão do agir científico como promotor não somente de progresso para a sociedade; consciência das implicações éticas).

Os palimpsestos se revelaram aí: nos traços de negociação que ora remetiam ao discurso midiático, como advindos do consumo simbólico no âmbito da mídia; ora remetiam a outras procedências, a exemplo das mediações de âmbito familiar. Esta polivalência de afetações culturais desvelou, em última análise, a própria complexidade da experiência dos sujeitos.

\section{REFERÊNCIAS}

BONIN, Jiani Adriana. Mídia e memórias: delineamentos para investigar palimpsestos midiatizados de memória étnica na recepção. Fronteiras/Estudos Midiáticos - v. 3, n. 2, maio/agosto, 2006.

COUTINHO, Andréa. Ficção Científica: narrativa do mundo contemporâneo. Revista de

Letras - Universidade Católica de Brasília. Disponível em http://portalrevistas.ucb.br/index.php/RL/article/view/27/59. Acesso em 16 de junho de 2011.

FAUSTO NETO, Antônio. Fragmentos de uma analítica da midiatização. Matrizes -. vol. 1, n. 2, abril/2008: São Paulo, pp. 89-105.

GARCÍA CANCLINI, Néstor. Consumidores e cidadãos: conflitos multiculturais da globalização. Rio de Janeiro: Editora UFRJ, 1999.

HALBWACHS, Maurice. A memória coletiva. São Paulo: Editora Centauro, 2004. 
MARTÍN-BARBERO, Jesús. Dos Meios às Mediações: comunicação, cultura e hegemonia. Rio de Janeiro: Editora UFRJ, 2006.

MARTINO, Luís Mauro Sá. Teoria da Comunicação: idéias, conceitos e métodos. Petrópolis, RJ: editora Vozes, 2009.

MEDEIROS, Theresa Christina Barbosa de. O futuro do presente: a mídia audiovisual e a sociedade contemporânea na ficção científica do cinema de animação. Dissertação de Mestrado apresentada ao Programa de Pós-graduação em Estudos da Mídia da UFRN. Natal (RN), 2011.

POLITSCHUK, Ilana; TRINTA, Aluízio Ramos. Teorias da Comunicação: o pensamento e a prática da Comunicação Social. Rio de Janeiro: Editora Campus, 2003.

SANTAELLA, Lúcia. A crítica das mídias na entrada do século 21. In PRADO, José Luiz Aidar. Crítica das práticas midiáticas: da sociedade de massa às ciberculturas. São Paulo: Hacker Editores, 2002.

SARLO, Beatriz. Tempo passado: cultura da memória e guinada subjetiva. Belo Horizonte: Editora UFMG, 2007.

SILVERSTONE, Roger. Por que estudar a mídia? São Paulo: edições Loyola, 2005.

SODRÉ, Muniz. Antropológica do Espelho: uma teoria da comunicação linear e em rede. Petrópolis, RJ: Editora Vozes, 2002.

WOLF, Mauro. Teoria das Comunicações de Massa. São Paulo: Martins Fontes, 2005.

Original recebido em: $30 / 10 / 2012$

Aceito para publicação em: 03/12/2012

Resumo sobre o autor

Emily Gonzaga de Araújo é Graduada em Comunicação Social pela Universidade Federal do Rio Grande do Norte. Mestre em Estudos da Mídia pela UFRN (2011); atualmente é professora no depto. de Comunicação Social da mesma instituição;

Kenia Beatriz Ferreira Maia é doutora em Ciência da Informação 
e da Comunicação - Université de Metz (2003). Professora do Departamento de Comunicação e Coordenadora do Programa de Pós-Graduação em Estudos da Mídia da UFRN. Vice-presidente da Associação Brasileira de Pesquisadores em Jornalismo (SBPJor). 